\title{
Effects of nitrogen forms on yield of sorghum (Andropogen sorghum) and their residual effect on a following wheat crop on a sandy soil.
}

\author{
M.H.Abdel-Aal, Mohamed I. Mohaseb and Marwa A. Ahmed \\ Soil, Water and Enviro.Res. Inst. (SWERI) - Agric. Res. C. (ARC), Giza-Egypt. \\ Correspondence author: amiro64@ymail.com
}

\begin{abstract}
Two field experiments were carried out on a sandy soil at Ismailia Agric. Res. Station, Ismailia governorate Egypt in a split plot design. The first experiment was during summer 2016 on sorghum (Andropogen sorghum, $v$. Dorado). The main plots contained treatments of fertilizer nitrogen forms, i.e. Ammonium Nitrate $33 \%$ N, Urea $46 \% \mathrm{~N}$ Urea Formaldehyde $40 \% \mathrm{~N}$ and Neem Coated Urea $40 \% \mathrm{~N}$ on sorghum. Four rates of i.e. 190,238and286 $\mathrm{Kg} \mathrm{N} / \mathrm{ha}(80,100$ and $120 \mathrm{~kg} \mathrm{~N} / \mathrm{fed})$ were arranged in the sub main plots. The second field experiment was carried out during the following winter, season of 2016- 2017 growing wheat (Tricticum aestivum), on the same plots of the first experiment, to study the residual effect. Results obtained the increases the rate of caused a significant increase in grains and straw yields of sorghum, as well as grain yield of the following wheat. The highest mean values of soil total- $\mathrm{N}$ as well as and available-N occurred after wheat harvest in soil given the $238 \mathrm{~kg} / \mathrm{ha}$ in rate as urea formaldehyde or Neem coated urea.
\end{abstract}

Key words: Ammonium Nitrate, Urea Formaldehyde, sorghum, wheat, Neem coated urea.

\section{Introduction}

Sandy soils represent the largest areas in Egypt, which can contribute in Egyptian expansion in agriculture. through reclamation of these soils. These soils have problems in plant nutrient. Therefore, one of the most important problems in sandy soils is the shortage in most essential nutrients especially nitrogen. $\mathrm{N}$ - fertilizers have marked and direct effects on yield of cereal crops. Readman et al.(2002) reported a high response of wheat grown on a sandy soil to $\mathrm{N}$ - fertilizers. Positive response of maize on sandy soils to $\mathrm{N}$ was observed by Shengmao et al.(2004). N-uptake by maize was reported to positively respond to N-fertilization. ( El-Gindy $\boldsymbol{e t}$ al. 2000). However, nitrogen added to sandy soil may be easily leached down through sandy soils due to their coarse texture. This is one of the reasons of $\mathrm{N}$ loss of added $\mathrm{N}$ - fertilizer. The form of $\mathrm{NO}_{3}-\mathrm{N}$ more easily lost by rapid leaching through the soil. Shengmao $\boldsymbol{e t}$ al. (2004) reported an accumulation of $\mathrm{NO}_{3}-\mathrm{N}$ in most subsoil layers and consequently less increase in crop yields grown on sandy soils.

Efforts have been devoted to solving this problem,. In this concern, slow release nitrogen fertilizers can be used, the slow release fertilizers include many forms such urea Formaldehyde (40\% $\mathrm{N})$. and coated urea which were with compared ammonium nitrate, ammonium sulphate and fertilizer applied to wheat grown on a sandy soil (Zeidan 2001) (Taalab and Badr 2007) compared calcium nitrate and ammonium sulphate applied to sorghum.

\section{Material and Methods}

A field experiment was carried out on a sandy soil at Ismailia Agricultural Research Station farm, Ismailia
Governorate, Egypt. Sorghum followed by wheat as tested crops were used to respond to $\mathrm{N}$ fertilization. Physical and chemical properties of these two soils under investigation are shown in Table (1). fertilizers were added to sorghum plant at rates of 190,238 and $286 \mathrm{Kg} / \mathrm{ha}$ (such rates represent 80,100 or $120 \%$ of the rate recommended for the crop in Ismailia. These rates were added in three equal doses after 3, 5 and 7 weeks respectively after planting. The plot area was $3 \times 4 \mathrm{~m}^{2}=12 \mathrm{~m}^{2}$. Wheat did not receive any $\mathrm{N}$ fertilization in order to evaluate the residual effect of these sources of $\mathrm{N}$ fertilizers.

\section{Experimental work:}

All forming processes were carried out before planting. Superphosphate $\left(15.5 \% \mathrm{p}_{2} \mathrm{O}_{5} \mid\right)$ was applied at rate of $100 \mathrm{~kg} /$ fed during tillage soil. Potassium sulfate was applied rate $75 \mathrm{~kg} \mathrm{k}_{2} \mathrm{O} /$ fed on two equal 30 and 55 day after planting.

Sorghum was planted on the 5 th of June 2016. Three plant samples from each plot were taken after 120 days of sowing at maturity stage. Wheat (triticum aestivum) variety Sakha 93 was sown is november 2016 on to study the residual effect of $\mathrm{N}$ application .At harvesting stage 20 may 2017. Surface soil samples from each plot were collected to determine total $\mathrm{N}$ and available.

\section{Methods of analyses:}

- Soil analysis

- The mechanical analysis was determined according to Piper (1950).

- Calcium carbonate was determined using the calcimeter as described by Piper (1950).

- Electrical conductivity (EC) was measured in soil paste extract using the method described by Page 
et al. (1982).

- Soluble cations: $\mathrm{Ca}^{++}$and $\mathrm{Mg}^{++}$were determined by titration using the versinate method, while $\mathrm{Na}+$ and $\mathrm{K}+$ were determined using flame photometer.

- Soluble anions: CO3--, $\mathrm{HCO} 3-$ and $\mathrm{Cl}$ - were determined titrimetrically according to Page et al. (1982).

- $\mathrm{pH}$ value was determined in 1:2.5 soil-water suspension using a glass-electrode $\mathrm{pH}$-meter.

- Organic matter content was determined according to the Walkley and Black (Jackson 1973).

- Available nitrogen was determined, as described by Page et al. (1982).

\section{Plant analyses}

The wet digestion method using conc. $\mathrm{H}_{2} \mathrm{So}_{4}$ and $\mathrm{H}_{2} \mathrm{O}_{2}$ was used as follows: $0.5 \mathrm{~g}$ oven - dry plant material was added in $50 \mathrm{ml}$ volumetric flask and digest with $10 \mathrm{ml} \mathrm{H} 2 \mathrm{SO} 4$ conc. on a hot plate at approximately $270{ }^{\circ} \mathrm{C}$ small quantities of $\mathrm{H} 2 \mathrm{O} 2$ was added repeatedly until the digest remains clear. Nitrogen, was determined as described by Chapman and Pratt (1961).

Table 1. Soil physical and chemical properties of the soils under investigation.

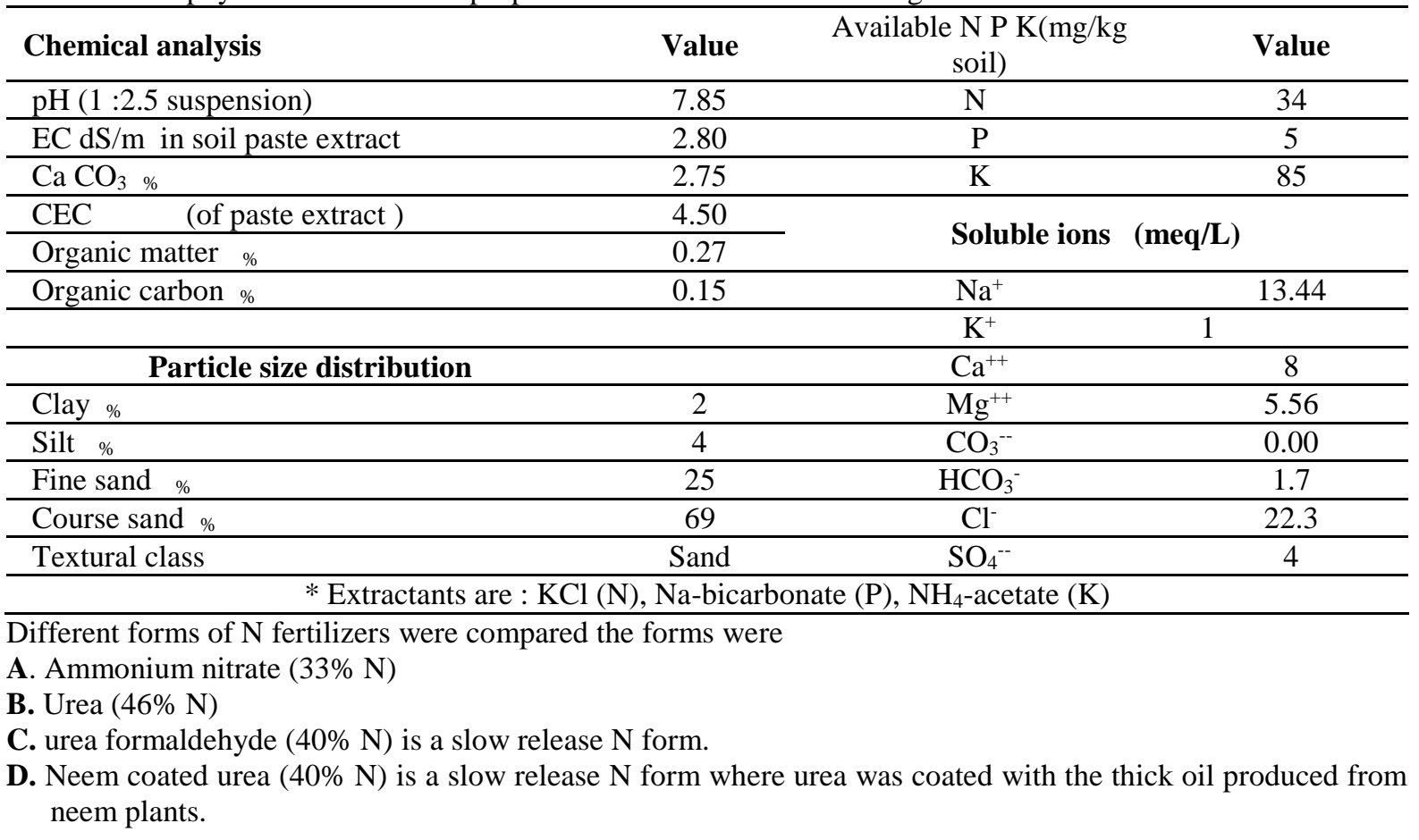

\section{Results and Discussion}

Plant heights as affected by the application of different $\mathrm{N}$-forms and rates.

Data of Table 2 show that, sorghum plant heights in both vegetative and blooming stages were not significantly increased using different $\mathrm{N}$-forms, while in maturity stage there were significant differences, where the ammonium nitrate gave the highest increase in plant heights Addition of any level for all $\mathrm{N}$-forms tended to a significant increase in the plant height, values for $238 \mathrm{~kg}$ or $286 \mathrm{~kg} \mathrm{~N} / \mathrm{ha}$ gave higher heights than $190 \mathrm{~kg} \mathrm{~N} / \mathrm{ha}$ and the non-traded. These data agree with Bahr et al. (2006) and ElYazied et al. (2007).

Wheat, as a tested crop for residual effect also responded to $\mathrm{N}$-forms and rates in cases of vegetative and maturity plant. There were significant differences among different $\mathrm{N}$ - forms. Urea formaldehyde gave the highest values of plant height compared with the other forms.. Plant height increased with using $190 \mathrm{~kg}$ $\mathrm{N} /$ ha level more than other rates, and values for the
$238 \mathrm{~kg}$ and $286 \mathrm{~kg} \mathrm{~N} / \mathrm{ha}$ were statistically the same. These result agree with Liao et al. (2006).

\section{Crop yield.}

Data in table 3 Show that sorghum grain and Straw yields as affected by application of nitrogen rates under different forms were significantly. Increasing the rate of all nitrogen forms caused a significant increase in sorghum yield (grains and Straw). The use of either ammonium nitrate or urea formaldehyde was more effective on grains yield attained with them were higher than with either urea or neem-coated urea. These results are similar to those reported by El-Etre et al. (2001), Zeidan et al. (2001) and El-Hussieny (2002) They reported that grain yield responded to $\mathrm{N}$ fertilization by any of urea forms in the range of 190.4 to $238 \mathrm{~kg} \mathrm{~N} / \mathrm{ha}$. These results are also in agreement with those obtained by Bharda et al.(2006), Bahr et al. (2006), El-Yazied et al. (2007), El-Hendawy and Hokam (2007) Abouziena et al. (2007) and Asibuo et al. (2008) Increasing of $\mathrm{N}$ rate up to $286 \mathrm{~kg} \mathrm{~N} / \mathrm{ha}$ caused light increase over that of 
$238 \mathrm{~kg} \mathrm{~N} / \mathrm{ha}$ for grain yield. Asibuo et al. (2008) showed that the increase of sorghum Straw yield was significant by using ammonium nitrate and urea formaldehyde fertilizers.

With regard to the residual effect of rates on wheat, yield responded to $\mathrm{N}$ rates and forms. The obtained data agree with those of Brennan and Bolland (2009), who showed a significant increase in the grain yield obtained with urea formaldehyde and lower yield by neem coated urea. These results agree with Cahill et al. (2007). The $\mathrm{N}$ application to sorghum was significant still effective at any of rates superiority. On other hand case of wheat straw yield for all $\mathrm{N}$-forms were statistically of the same effect. The $\mathrm{N}$ - rates were recorded the same effect on grain yield.

Table 2. Plant height $(\mathrm{cm})$ for Sorghum and wheat plants (at harvest) affected by different N-rates using different $\mathrm{N}$ - forms.

\begin{tabular}{|c|c|c|c|c|c|c|}
\hline \multirow{2}{*}{\multicolumn{2}{|c|}{ Crop }} & \multirow{3}{*}{$\begin{array}{c}\text { form of } \mathbf{N}(\mathrm{F}) \\
\text { (A) }\end{array}$} & \multicolumn{3}{|c|}{ Rate of N (kg/ha.) (R) } & \multirow{3}{*}{$\begin{array}{l}\begin{array}{l}\text { Mean of plant } \\
\text { height }(\mathbf{c m})\end{array} \\
71.50\end{array}$} \\
\hline & & & \multirow{2}{*}{$\begin{array}{c}\mathbf{1 9 0} \\
71.50\end{array}$} & \multirow{2}{*}{$\begin{array}{c}\mathbf{2 3 8} \\
75.75\end{array}$} & \multirow{2}{*}{\begin{tabular}{|c|}
$\mathbf{2 8 6}$ \\
80.00
\end{tabular}} & \\
\hline \multirow{5}{*}{ 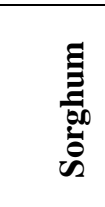 } & \multirow{5}{*}{ 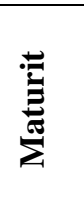 } & & & & & \\
\hline & & (B) & 65.50 & 64.25 & 67.50 & 64.00 \\
\hline & & (C) & 67.75 & 74.25 & 73.25 & 68.50 \\
\hline & & (D) & 64.75 & 68.75 & 73.50 & 66.44 \\
\hline & & Mean & 67.38 & 70.75 & 73.56 & \\
\hline \multirow{5}{*}{ 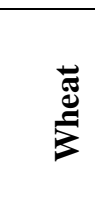 } & \multirow{5}{*}{ 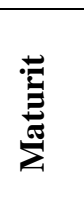 } & (A) & 50.25 & 49.00 & 49.50 & 47.69 \\
\hline & & (B) & 47.50 & 48.75 & 45.25 & 45.88 \\
\hline & & (C) & 55.75 & 50.25 & 48.75 & 49.19 \\
\hline & & (D) & 47.00 & 51.50 & 48.75 & 47.31 \\
\hline & & Mean & 50.13 & 49.88 & 48.06 & \\
\hline \multicolumn{2}{|c|}{ L.S.D. at 0.05 level } & $\begin{array}{l}\text { Sorghum } \\
\text { Wheat }\end{array}$ & $\begin{array}{l}R=5.6 \\
R=2.9\end{array}$ & $\begin{array}{l}F^{*} \mathbf{R}=\mathbf{n . s} \\
\mathbf{F} * \mathbf{R}=\mathbf{n . S}\end{array}$ & & \\
\hline
\end{tabular}

Notes: A. Ammonium nitrate $(33 \% \mathrm{~N})$

C. Urea formaldehyde $(40 \% \mathrm{~N})$

B. Urea $(46 \% \mathrm{~N})$

D. Neem coated urea $(40 \% \mathrm{~N})$

Table 3. Straw and grains yields of sorghum and wheat crop (tons/ha.) as affected by application of different Nrates using different $\mathrm{N}$-forms.

\begin{tabular}{|c|c|c|c|c|c|c|}
\hline \multirow{2}{*}{\multicolumn{2}{|c|}{ Crop }} & \multirow{3}{*}{$\begin{array}{c}\text { form of } \mathrm{N} \\
\text { (A) }\end{array}$} & \multicolumn{3}{|c|}{ Rate of N (kg/ha) } & \multirow{3}{*}{$\begin{array}{c}\text { Mean } \\
\mathbf{5 . 2 0} \\
\end{array}$} \\
\hline & & & \multirow{2}{*}{\begin{tabular}{|l|}
190 \\
3.21 \\
\end{tabular}} & \multirow{2}{*}{\begin{tabular}{|l|}
$\mathbf{2 3 8}$ \\
5.81 \\
\end{tabular}} & \multirow{2}{*}{$\begin{array}{l}\mathbf{2 8 6} \\
6.59 \\
\end{array}$} & \\
\hline \multirow{10}{*}{ 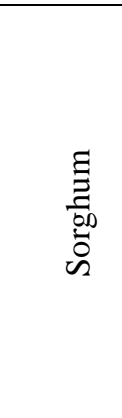 } & \multirow{5}{*}{ שֶ } & & & & & \\
\hline & & (B) & 1.93 & 4.24 & 6.09 & 4.09 \\
\hline & & (C) & 2.55 & 5.45 & 6.93 & 4.98 \\
\hline & & (D) & 1.71 & 3.69 & 2.52 & 2.64 \\
\hline & & Mean & 2.35 & 4.80 & 5.53 & \\
\hline & \multirow{5}{*}{$\sum_{\pi}^{\pi}$} & (A) & 3.52 & 3.89 & 4.4 & 3.24 \\
\hline & & (B) & 2.73 & 3.43 & 4.32 & 2.91 \\
\hline & & (C) & 3.73 & 4.05 & 5.43 & 3.59 \\
\hline & & (D) & 2.29 & 3.66 & 2.91 & 2.51 \\
\hline & & Mean & 3.07 & 3.76 & 4.27 & \\
\hline \multirow{10}{*}{$\sum_{\tilde{\Xi}}^{\tilde{E}}$} & \multirow{5}{*}{ 苞 } & (A) & 1.90 & 1.81 & 2.62 & 2.11 \\
\hline & & (B) & 1.71 & 2.12 & 2.48 & 2.10 \\
\hline & & (C) & 1.93 & 2.62 & 3.07 & 2.54 \\
\hline & & (D) & 1.24 & 1.81 & 1.83 & 1.63 \\
\hline & & Mean & 1.70 & 2.09 & 2.5 & \\
\hline & \multirow{5}{*}{$\sum_{\bar{E}}^{B}$} & (A) & 3.78 & 3.12 & 4.28 & 3.73 \\
\hline & & (B) & 3.07 & 3.52 & 3.31 & 3.3 \\
\hline & & (C) & 3.43 & 4.09 & 3.86 & 3.79 \\
\hline & & (D) & 2.50 & 3.86 & 3.86 & 3.41 \\
\hline & & Mean & 3.20 & 3.65 & 3.83 & \\
\hline \multicolumn{7}{|c|}{$\begin{array}{c}\text { Sorghum Grain } F=0.47 \quad R=0.33 \quad F^{*} R=n . s \\
\text { Wheat Grain } F=0.25 \quad R=0.19 \quad F^{*} R=n . s .\end{array}$} \\
\hline
\end{tabular}
A. Ammonium nitrate $(33 \% \mathrm{~N})$
B. Urea $(46 \% \mathrm{~N})$
C. Urea formaldehyde $(40 \% \mathrm{~N})$
D. Neem coated urea $(40 \% \mathrm{~N}$ 


\section{Nitrogen uptake mg / plant.}

Data of nitrogen uptake by sorghum and wheat plants, respectively at in Table 4, Ammonium nitrate gave the highest grain yiled followed by urea formaldehyde while neem- coated urea gave the lowest for sorghum. Straw yield of sorghum were highest by urea- formaldehyde; followed by ammonium nitrate and, neem- coated urea gave the lowest. Concurring wheat yield of grains as well as straw, urea- formaldehyde gave the highest followed by ammonium nitrate while neem- coated urea gave the lowest . Such patterns with all $\mathrm{N}$ rates. Increased rates of $\mathrm{N}$ was associated with increased yields, and this occurred with all forms of $\mathrm{N}$. N uptake in all cases. These results gave with those of El-Gindy et al. (2000) and Abd-El-Monem et al. (1995).

Table 4 Nitrogen uptake (mg/plant) by sorghum and wheat plants as affected by application of different $\mathrm{N}$ rates using different $\mathrm{N}$-forms

\begin{tabular}{|c|c|c|c|c|c|c|}
\hline \multirow{2}{*}{\multicolumn{2}{|c|}{ Crop type }} & \multirow{3}{*}{$\begin{array}{c}\text { N-form } \\
\text { (A) }\end{array}$} & \multicolumn{3}{|c|}{ N-Rate (kg/ha). ( R ) } & \multirow{3}{*}{$\begin{array}{l}\text { Mean } \\
110.47\end{array}$} \\
\hline & & & 190 & 238 & 286 & \\
\hline \multirow{10}{*}{ 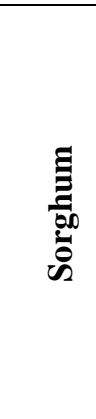 } & \multirow{5}{*}{ 节 } & & 89.73 & 110.77 & 130.88 & \\
\hline & & (B) & 119.43 & 141.30 & 71.14 & 110.62 \\
\hline & & (C) & 204.42 & 138.06 & 135.09 & 159.19 \\
\hline & & (D) & 71.71 & 79.25 & 90.87 & 80.61 \\
\hline & & Mean & 121.32 & 117.35 & 107 & \\
\hline & \multirow{5}{*}{$\frac{\overrightarrow{0}}{\dot{D}}$} & (A) & 71.11 & 86.35 & 107.08 & $\mathbf{8 8 . 1 8}$ \\
\hline & & (B) & 86.89 & 89.44 & 71.14 & 82.49 \\
\hline & & (C) & 137.97 & 131.45 & 135.11 & 134.84 \\
\hline & & (D) & 61.67 & 71.76 & $\begin{array}{l}90.87 \\
\end{array}$ & \begin{tabular}{|l|l|}
74.77 \\
\end{tabular} \\
\hline & & Mean & 89.41 & 94.75 & 101.03 & \\
\hline \multirow{10}{*}{$\sum_{\vec{E}}^{\vec{E}}$} & \multirow{5}{*}{ 总 } & (A) & 37.37 & 32.58 & 41.67 & 37.21 \\
\hline & & (B) & 32.49 & 30.39 & 43.82 & 35.57 \\
\hline & & (C) & 30.87 & 39.48 & 53.81 & 41.39 \\
\hline & & (D) & $\begin{array}{l}19.75 \\
\end{array}$ & 23.23 & 16.54 & 19.84 \\
\hline & & Mean & 30.12 & 31.42 & 38.96 & \\
\hline & \multirow{5}{*}{$\stackrel{E}{E}$} & (A) & 18.09 & 27.56 & 23.85 & 23.17 \\
\hline & & (B) & 22.28 & 30.18 & 16.90 & 23.12 \\
\hline & & (C) & 22.13 & 28.04 & 14.38 & 21.52 \\
\hline & & (D) & 24.32 & 37.37 & 55.74 & 39.14 \\
\hline & & Mean & 21.71 & \begin{tabular}{|c|}
30.79 \\
\end{tabular} & 27.72 & \\
\hline
\end{tabular}

\section{N- forms:-}

A. Ammonium nitrate $(33 \% \mathrm{~N})$
C. Urea formaldehyde $(40 \% \mathrm{~N})$

B. Urea $(46 \% N)$

D. Neem coated urea $(40 \% N$

\section{N- uptake}

Table 5 represent total $\mathrm{N}$ uptake by Urea formaldehyde gave highest uptake than urea and neem coated urea, in sorghum. Bahr et al. (2006) and ElYazied et al. (2007), showed that urea- formaldehyde gave high $\mathrm{N}$ uptake in wheat the crop of residual effect was not statistically affected with different $\mathrm{N}$-forms. All rates were significantly effective in increasing Nuptake in wheat The rates were of ascending affect according to their applications. The $286 \mathrm{~kg} \mathrm{~N} / \mathrm{ha}$ was superior to the $190 \mathrm{~kg} \mathrm{~N} / \mathrm{ha}$. As for $\mathrm{N}$ recovery of sorghum and wheat, urea formaldehyde caused higher uptake than urea and neem coated urea. The rates used in applications were of similar effect. Ammonium nitrate was the only form which increased proportionally by increasing the application rates. Urea formaldehyde showed the highest efficienc followed with urea, ammonium nitrate and neem coated urea. Readman et al. (2002) \& Singh et al. (1995) obtained trends similar to the present study. 
Table 5. $\mathrm{N}$ uptake (kg/ha.) by sorghum and wheat crops as affected by $\mathrm{N}$ rates using different $\mathrm{N}$-forms.

\begin{tabular}{|c|c|c|c|c|c|}
\hline \multirow{2}{*}{ Crop } & \multirow{2}{*}{ N-forms $(\mathbf{F})$} & \multicolumn{3}{|c|}{ N-Rates (kg/ha) (R ) } & \multirow{2}{*}{ Mean } \\
\hline & & 190 & 238 & 286 & \\
\hline \multirow{5}{*}{ 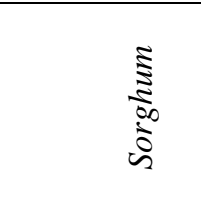 } & (A) & 160.84 & 197.11 & 237.95 & 198.63 \\
\hline & (B) & 206.32 & 230.74 & 142.28 & 193.11 \\
\hline & (C) & 342.39 & 269.51 & 270.20 & 294.03 \\
\hline & (D) & 133.38 & 151.01 & 181.74 & 155.38 \\
\hline & Mean & 210.73 & 212.09 & 208.04 & \\
\hline \multirow{5}{*}{$\frac{\vec{\Xi}}{\stackrel{\Xi}{z}}$} & (A) & 55.45 & 60.14 & 65.52 & 60.37 \\
\hline & (B) & 54.76 & 60.57 & 60.71 & 58.68 \\
\hline & (C) & 53.00 & 67.52 & 68.19 & 62.90 \\
\hline & (D) & 44.08 & 60.59 & 72.28 & 58.98 \\
\hline & Mean & 21.78 & 26.14 & 28.01 & \\
\hline \multirow{5}{*}{ 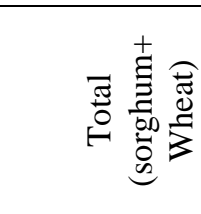 } & (A) & 216.29 & 257.25 & 303.47 & 259 \\
\hline & (B) & 261.09 & 291.31 & 202.99 & 251.80 \\
\hline & (C) & 395.39 & 337.03 & 338.39 & 356.94 \\
\hline & (D) & 177.45 & 211.61 & 254.02 & 214.36 \\
\hline & Mean & 262.56 & 274.3 & 274.72 & \\
\hline \multicolumn{6}{|c|}{ 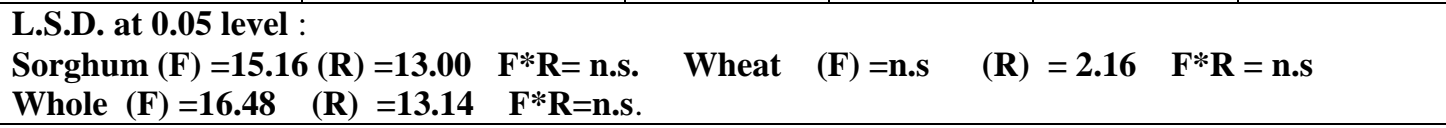 } \\
\hline
\end{tabular}

\section{N-Forms}
A. Ammonium nitrate $(33 \% \mathrm{~N})$
C. Urea formaldehyde $(40 \% \mathrm{~N})$
B. Urea $(46 \% \mathrm{~N})$
D. Neem coated urea $(40 \% \mathrm{~N})$

\section{Nitrogen status in soil:}

Available $\mathrm{N}$ as affected by nitrogen forms at different rates were determined after 4 months of application to study the nitrogen status in soil. The data are presented in Table 6 . Available $\mathrm{N}$ in soil was lowest
$190 \mathrm{~kg} \mathrm{~N} / \mathrm{ha}(58.68 \mathrm{mg} / \mathrm{kg}$ soil) by urea- formaldehyde at lowest rate and highest $(98.37 \mathrm{mg} / \mathrm{kg}$ ) by same form at highest rate $(286 \mathrm{kgN} / \mathrm{ha})$. The used of $\mathrm{N}$ - form and different rate were significant increase for available $\mathrm{N}$ in soil.

Table 6. Available nitrogen in soil (mg/kg soil) as affected by different $\mathrm{N}$ rates with using different $\mathrm{N}$-forms.

\begin{tabular}{|c|c|c|c|c|}
\hline \multirow{2}{*}{ N-Form ( F) } & \multicolumn{3}{|c|}{ N- Rate (kg/ha) ( R ) } & \multirow{2}{*}{ Mean } \\
\cline { 2 - 4 } & $\mathbf{3 9 0}$ & $\mathbf{2 3 8}$ & \multirow{2}{*}{$\mathbf{2 8 6}$} \\
\cline { 2 - 4 } Available N & $\mathbf{7 8 . 8 0}$ \\
\hline (A) & 69.02 & 81.71 & 85.68 & $\mathbf{7 2 . 9 9}$ \\
\hline (B) & 68.23 & 74.57 & 76.16 & $\mathbf{8 4 . 0 8}$ \\
\hline (C) & 58.68 & 95.2 & 98.37 & $\mathbf{8 0 . 3 9}$ \\
\hline Mean & 72.99 & 83.3 & 84.89 & $\mathbf{8 6 . 2 8}$ \\
\hline L.S.D. at 0.05 level : & $\mathbf{6 7 . 2 3}$ & $\mathbf{8 3 . 7 0}$ & $(\mathrm{F})=4.15 \mathrm{R}=4.15$ & $\mathrm{~F}^{*} \mathrm{R}=9.29$ \\
\hline
\end{tabular}

N-Forms:

A. Ammonium nitrate $(33 \% \mathrm{~N})$
C. Urea formaldehyde $(40 \% \mathrm{~N})$

\section{References}

Abd-El-Monem, M., Lindsay, W.L., Sommer, R. and Ryan, J. (2010). Loss of nitrogen from urea applied to rainfall wheat in varying rainfall zones in northern Syria. Nutrient Cycling in Agroecosystems. 86 (3): 357-366.

Abouziena, H.F., El-Karmany, M.F., Singh, M. and Sharma, S.D. (2007). Effect of nitrogen rates and weed control treatments on maize yield and associated weeds in sandy soils.Weed Technology. 21(4):1049-1053.

Asibuo, J.Y., Safo, E.Y., Adjei, B.A. and Bonsu, P.O. (2008). Residual effect of leguminous crops
B. Urea $(46 \% \mathrm{~N})$

D. Neem coated urea $(40 \% \mathrm{~N})$ and inorganic fertilizer on soil properties and maize grain yield. Acta Agronomica Hungarica. 56 (3): 295-301.

Bahr, A.A., Zeidan, M.S. and Hozayn, M. (2006). Yield and quality of maize (Zea mays L.) as affected by slow-release nitrogen in newly reclaimed sandy soil. American-Eurasian Journal of Agricultural and Environmental Science. 1(3): 239-242.

Bharda, N.M., Shivay, Y.S., Prasad, R., Kumar, D. and Singh, S. (2006). Effect of blending urea with neem-oil with and without biogass slurry on ricewheat cropping system. Indian Journal of Fertilizers. 2 (7): 37-42. 
Brennan, R.F. and Bolland, M.D. (2009). Comparing the nitrogen and phosphorus requirements of canola and wheat for grain yield and quality. Crop and Pasture Science 60(6): 566577.

Cahill, S., Osmond, D., Crozier, C., Israel, D.W. and Weisz, R. (2007). Winter Wheat and Maize Response to Urea Ammonium Nitrate and a New Urea Formaldehyde Polymer Fertilizer. Agronomy Journal. 99(6): 1645-1653.

Chapman, H.D. and Pratt, P.F. (1961). Methods of Analysis for Soil, Plant and water. Calif., Univ. USA.

El-Etre, W.M., Ali, M.E., El-Akel, E.A. and Bayoumi, M.S. (2001). Growth and nutrient content of wheat plant as influenced by different sources of nitrogen and iron in some soils of Egypt. Annals of Agricultural Science, Moshtohor. 39(1): 749-762.

El-Gindy, A.M., Mahmoud, M.H. and El-Guibali, A.H. (2000). Effect of irrigation methods, various fertilizer sources and rates on Faba bean plants and residual effect on subsequent corn. Annals of Agricultural Science (Cairo). (1):157-173.

El-Hendawy, S.E. and Hokam, E.M. (2007). Drip irrigation frequency: the effects and their interaction with nitrogen fertilization on sandy soil water pattern, corn yield and water use efficiency under Egyptian conditions. 8th African Crop Science Society Conference, El-Minia, Egypt, (27):1491-1503.

El-Hussieny, O.H. (2002). Polyacrylamide-N forms combination simulating some newly reclaimed soils as related to micronutrients uptake by the grown plants. Annals of Agricultural Science, Moshtohor. 40(3): 1935-1948.

El-Yazied, A.A., Ragab, M.E., Rawia, E.I., ElWafa, S.M. (2007). Effect of nitrogen fertigation levels and chelated calcium foliar application on the productivity of sweet corn. Arab Universities Journal of Agricultural Sciences. 15(1): 131-139.
Jackson, M.L. (1973). Soil Chemical Analysis, Prentice Hall Inc., Englewood Cliffs, U.S.A.

Liao, M.T., Palta, J.A. and Fillery, I.R. (2006). Root characteristics of vigorous wheat improve early nitrogen uptake. Australian Journal of Agricultural Research. 57(10):1097-1107.

Ouyang, D.S., MacKenzie, A.F. and Fan, M.X. (1999). Availability of banded triple superphosphate with urea and phosphorus use efficiency by corn. Nutrient Cycling in Agroecosystems. 53(3): 237-247.

Page, A.L., Miller, R.H. and Keeney, D.R. (1982). Methods of Soil Analysis 11- Chemical and Microbiological properties. Soil Sci. Amer. Madison Wisconsin, U.S.A.

Piper, C.S. (1950). "Soil and plant analysis" Univ. of Adelaide Australia

Readman, R.J., Beckwith, C.P. and Kettlewell, P.S. (2002). Effects of spray application of urea fertilizer at stem extension on winter wheat: $\mathrm{N}$ recovery and nitrate leaching. Journal of Agricultural Science.139 (1): 11-25.

Shengmao, Y., Fengmin, L., Sukhdev, S. M., Ping, $W$., Dongrang, $S$. and Jianguo, $W$. (2004). Long-Term Fertilization Effects on Crop Yield and Nitrate Nitrogen Accumulation in Soil in Northwestern China. Agronomy Journal. 96 (4): 1039-1049.

Singh, J.P., Dahiya, D.J. and Kumar, V. (1995). Effect of nitrogen and iron supply on the growth and nutrient uptake of wheat grown on sandy soil. Crop Research. 10(3): 271-276.

Taalab, A.S. and Badr, M. A. (2007). Phosphorus availability from compacted rock phosphate with nitrogen to sorghum inoculated with phosphobacterium. Journal of Applied Sciences Research. 3(3): 195-201.

Zeidan, M.S. and El-Kramany, M.F. (2001). Effect of organic manure and slow-release $\mathrm{N}$-fertilizers on the productivity of wheat (Triticum aestivum L.) in sandy soil. Acta Agronomica Hungarica. 49 (4):379-385. 


\section{تاثيرات صور النيتروجين المختلفة والتاثير المتبقي لها على محصول الذرة الرفيعة والققح فى الارض الرملية. \\ محمد حافظ عبد العال - محمد ابراهيم محسب - مروة عبدة احمد لهائرئ \\ معهز بحوث الأراضى والمياه والبيئة-مركز البحوث الزراعية (مصر -الجيزة )}

تهذف هذه الدراسة إلى تحديد أنسب صورة من صور النسميد الأزوتى والتى يمكن إضافتها إلى الأراضى المستصلحة حديثا ، متل

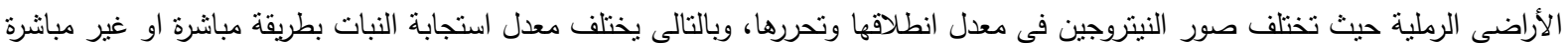
نتيجة لإضافة صور النيتروجين. لتحقيق هذا الهدف أجريث تجربة فى ارض رملية بمحطة بحوث الإسماعيلية فى تصميم احصائى قطع منثقة. المعاملات الرئيسية كانت

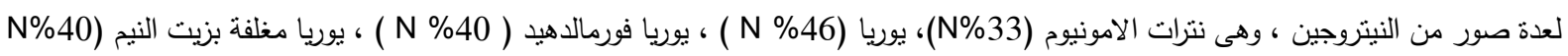

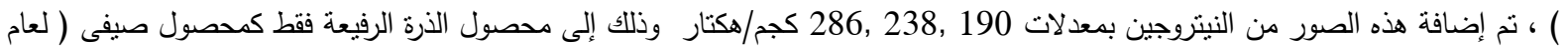

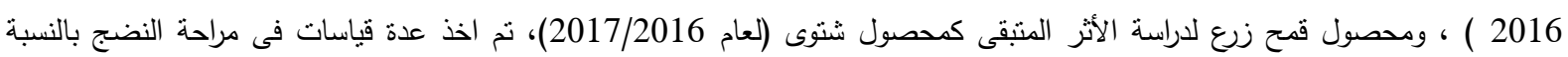

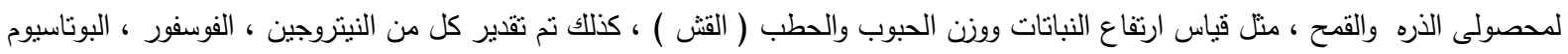

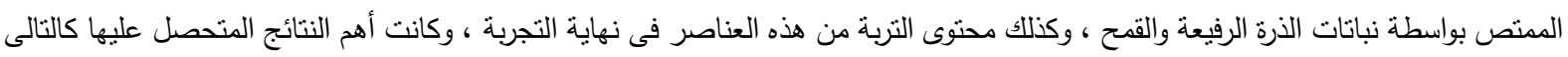

طول النبات لكل من حطب الذرة الرفيعة وقش القمح زاد بزيادة معنويا بزيادة معدلات اضافة النيتروجين ، كما أعطت اليوريا فورمالدهيد فى حالة الذرة الرفيعة والقمح أعلى القيم. زاد محصول الحبوب للذرة الرفيعة زيادة مقبولة بزيادة معدل إضافة النيتروجين ، استجاب محصول الحبوب للقمح إلى التأثيرات الكتبقية لهذه الإضافات حتى 286كجم نيتروجين/هكتار، وكانت افضل النتائج مع اضافة اليوريا فورمالدهيد عند اعلى معدل. حطب الذرة الرفيعة وقش القمح قد سلكا نفس سلوك مانك محصول الحبوب.

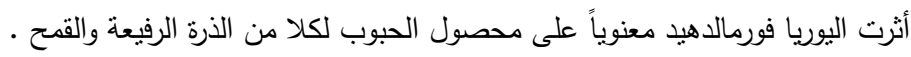

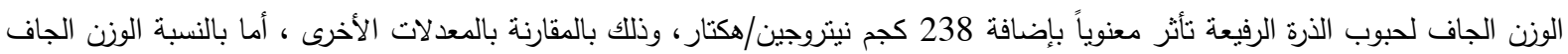

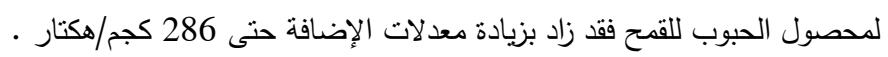
زاد النيتروجين الممتص معنوياً باستخدام اليوريا فورمالدهيد مقارنة بباقى صور النيتروجين الأخرى فى حالة الحطب للذارة الرفيعة والحبوب لمحصول القمح كتأثير متنقى.

زاد محتوى النيتروجين فى القش معنويا بزيادة معدلات الإضافة.

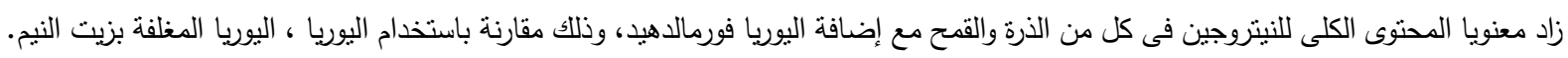

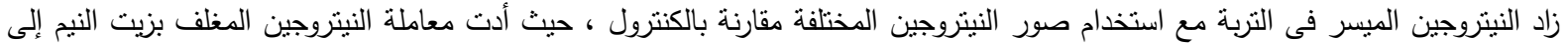
زيادة محتوى النيتروجين بالتزبة أعلى من الصور الأخرى. 